\title{
GOING BEYOND AGGREGATED MEASURES IN THE CONDITIONAL CASH TRANSFER PROGRAMS: THE EFFECTIVE COVERAGE OF BENEFITS AND BENEFICIARIES
}

\author{
INDO ALÉM DAS MEDIDAS AGREGADAS EM PROGRAMAS DE \\ TRANSFERÊNCIAS MONETÁRIAS CONDICIONADAS: A COBERTURA \\ EFETIVA DE BENEFÍCIOS E BENEFICIÁRIOS
}

\begin{abstract}
Gibrán Cruz-Martínez $z^{(*)}$
Universidad Autónoma de Chile

Institute of Latin American Studies School of Advanced Study, University of London
\end{abstract}

\begin{abstract}
The purpose of this paper is to present two alternative indicators in order to rethink and reevaluate the coverage of conditional cash transfer programs (CCTs) in Latin America and the Caribbean (LAC). The term effective coverage, introduced by the World Health Organization, was used as a reference to adjust the aggregate indicators on the ECLAC database taking into account the target population of the programs. Effective coverage of beneficiaries is a metric that shows the potential proportion of population living in monetary poverty that benefits from the CCTs. Effective coverage of benefits shows the potential proportion of the monetary poverty line value invested by the CCTs. Only three CCTs presented an effective coverage of beneficiaries higher than the total population in monetary poverty, and nine over the total population in extreme monetary poverty. Meanwhile, ten CCTs presented an effective coverage of benefits higher than the extreme monetary poverty line value, and seven higher than the monetary poverty line value.

Keywords: Conditional cash transfer programs, Poverty; Latin America and the Caribbean.

Resumo: O propósito deste artigo é apresentar dois indicadores alternativos para repensar e reavaliar a cobertura de Programas de transferências monetárias condicionadas (TMCs) na América Latina e no Caribe (ALC). O termo cobertura efetiva, introduzido pela Organização Mundial de Saúde, foi usado como referência para ajustar indicadores agregados na base de dados CEPAL, considerando-se a população alvo dos programas. A cobertura efetiva dos beneficiários é uma métrica para mostrar a potencial proporção da população vivendo em pobreza monetária, beneficiária dos TMCs. A cobertura efetiva de benefícios mostra a potencial proporção do valor da linha da pobreza monetária investido pelos TMCs. Apenas três TMCs apresentaram uma cobertura efetiva de beneficiários mais alta do que a população total na pobreza monetária, e nove sobre a população total em pobreza monetária extrema. Entretanto, dez TMCs apresentaram uma cobertura efetiva de benefícios mais alta do que o valor da linha de pobreza monetária extrema, e sete, mais alta do que o valor da linha de pobreza monetária.
\end{abstract}

Palavras-chave: Programas de transferências monetárias condicionadas; Pobreza; América Latina e Caribe.

$(*) \quad$ PhD in Political Science at the Universidad Complutense de Madrid; Associate Researcher at the Universidad Autónoma de Chile and Visiting Fellow at the Institute of Latin American Studies, University of London. E-mail: gcruz@ichem. cl. Received in: 29.12.2015, accepted in: 23.2.2016. 


\section{INTRODUCTION}

The main purpose of this article is to present an alternative perspective on the effective coverage of the main anti-poverty social policy in Latin America and Caribbean: the conditional cash transfer programs (CCTs). These programs use targeting to alleviate monetary poverty and extreme poverty through conditional cash transfers. Conditionality is primarily used to promote health, nutrition and education of the beneficiaries and/ or their children. Through conditionality these programs seek to develop the human capital of the population on income poverty, encouraging their development of basic capabilities and reducing intergenerational inequalities of opportunities.

After the so-called 'lost decade', most of the countries in Latin America and Caribbean began betting on the CCTs as a solution to reduce the high levels of poverty and inequality. The commitment to these programs was not spontaneous but arises from 'imposed recommendations' of international financial institutions. According to (SÁNCHEZ DE DIOS, 2012, p. 172-173), financial institutions like the International Monetary Fund started to gain important influence capacity after the debt crisis of the 1980's. "With the support of domestic groups [and] using the 'structural adjustment' label, these agents imposed tough austerity measures combined with policies that reoriented production towards exports and programs to reduce state intervention [...]"(1). The CCTs were an important part of structural adjustment policies since they operated as 'fire extinguishers' due to the economic crisis suffered and resisted by the population, especially by those living in poverty.

The CCTs have been implemented in almost all countries in the region. By 2007 these programs were benefiting more than seventy million Latin Americans, i.e. about $12 \%$ of the population had coverage (ECLAC, 2007). By December 2010, the CCTs were operating in eighteen countries of the region and benefiting more than 25 million families - about 113 million people. This means that at that time, about 19\% of the Latin American population were beneficiaries of the CCTs (MOLINARI, 2010). Stampini and Tornarolli (2012) slightly raise the number of population covered in 2011 by at least one CCT to 129 million. In a recent publication, it was confirmed that the number of countries that had implemented such programs had increased to twenty. Similarly, from 2010 to 2012 the number of beneficiaries increased to 127 million people, i.e. around $21 \%$ of the population (ECLAC and ILO, 2014).

Its temporal periodicity to mitigate the consequences of the 'structural adjustment' was prolonged, and today these programs are the main tool of public policy against poverty $^{(2)}$. Now, is it possible to identify comparable data of CCTs in the region that allow assessing the level of coverage of the targeted population? What proportion of the population with income below the poverty line is a beneficiary of the main CCT

(1) Translated by the author.

(2) It would be relevant to ask why these programs after nearly a quarter century since its creation are still in place in virtually every country in Latin America. It is possible to deduce two reasons: first, because of the low effectiveness of structural reforms to redistribute the benefits of economic development in the region; second, the possible reception of these programs by governments as a clientelistic tool to gain/increase popular support. 
in each country? What proportion of the monetary poverty line value is invested per beneficiary? To answer these questions it was necessary to readjust and review the data published in the United Nations Economic Commission for Latin America and the Caribbean (ECLAC) database. Through the construction of two alternative indicators, this paper seeks to produce two comparable alternative indicators ${ }^{(3)}$ on the coverage of beneficiaries and the monetary benefits, focusing the analysis on the group of the population targeted by CCTs, i.e. the population on income poverty.

The paper is organized as follows. The next section briefly presents the CCTs experience of residualism and targeting in the region. The third section conducts a literature review on CCTs previous analysis and results. Later on, the paper presents the main results of the two alternative indicators to measure coverage in the CCTS: effective coverage of benefits and effective coverage of beneficiaries. The article finalize with a general conclusion.

\section{RESIDUALISM AND TARGETING IN THE CONDITIONAL CASH TRANSFER PROGRAMS}

Targeted programs like the CCTs are typical of the residual welfare regimes. In this model the individual has a leading role satisfying individual social risks and ensuring his/her wellbeing. In addition, a high dependence on the market (commodification of welfare) is evident, with a marginal role of families and a targeted public provision (public residualism) (ESPING-ANDERSEN, 1990; DEL VALLE, 2010). In the residual model, the state intervenes to satisfy social risks through social safety nets targeted to a stigmatized group of individuals considered as 'incapables' of safeguarding their welfare through the labor market. These are the beneficiaries of the CCTs. The conditionality of targeted programs is not a compulsory trait. In the case of CCTs, the conditionality is present.

Draibe and Riesco, (2009, p. 25) suggested that the CCTs constituted an important innovation in the social protection systems of Latin America, as they began to link targeted and universal basic programs. Targeting is evidenced by means testing as a condition to become a recipient of cash transfers. On the other hand, the promotion of universal basic services in the education and health areas were encouraged by the CCTs as regular visits to a healthcare specialist and children school enrollment were conditions to receive the cash transfers in many cases.

From a gender perspective, Tabbush (2010) has argued that women recipients of cash transfers are empowered and their economic autonomy is enhanced within the family unit. However, using the case of Chile, the authors demonstrated how CCTs portrays women as the solely responsible for family welfare. Thus these programs rather than reduce welfare familiarization ${ }^{(4)}$, they perpetuate it. (ADATO and HODDINOTT,

\footnotetext{
(3) These alternative indicators will present the highest level of effective coverage of benefits and beneficiaries assuming perfect selectivity in the programs. See discussion about this in Section 4.

(4) Makes reference to the dependence in the family unit for individual welfare.
} 
2010 p. 285) highlighted the virtue of the CCTs in terms of empowerment of women. However, they mentioned a study of Kabeer (1999) where the scholar questioned the fact that being the recipient of cash transfers actually increases the decision-making power of women on how to spend the money or their ability to negotiate in the marital relationship. Basically, the author argues if these programs actually increase the power resources of women within the marital relationship.

Reimers et al. (2006) showed that in terms of education, the CCTs only have a significant effect promoting an increased in the enrollment rates and school attendance when they are initially very low, but do not produce positive effects on the students learning process. (LOMELÍ, 2009, p.168-169) considers that previous evaluations of CCTs have shown an improvement in the areas of health and nutrition of the beneficiaries, an increase in the number of years that children remain in the education system and slight reductions in poverty and inequality. However, the author outlines six illusions created by the positive results of the CCTs. Just to mention some: (1) an economic illusion, with the causal rhetorical discourse between investing in human capital (education, health, nutrition) and the automatic and consequently increase in the income of beneficiaries through the labor market; and (2) the social illusion that CCTs are effective in reducing poverty when the results show a reduction in the severity of monetary deprivations, but not necessarily a poverty reduction (CORTÉS et al., 2007; SKOUFIAS et al., 2001).

According to the ECLAC (2010), while social spending in the region is around $18 \%$ of GDP, the CCTs programs only accounts for $0.40 \%$ of GDP. Only 33\% of CCTs in Latin America effectively monitors the achievement of conditionalities (VILLATORO and RIVERA, 2007). On this regard, Slater (2011) considers that targeting and conditioning in social policy should be avoided when the administrative capacity of governments is low. He argues that by discarding the possibility of conditioning and targeting, the only possible solution is the extension of universal transfers.

\section{ALTERNATIVE INDICATORS TO PRESENT THE POTENTIAL EFFECTIVENESS OF THE CCTS IN REDUCING INCOME POVERTY}

The ECLAC (2014) 'Non-contributory social protection programmes in Latin America and the Caribbean' database exhibits the main CCTs in each country of the region (see Table 1). Data is available for 49 CCTs - existing and extinct - from 21 countries in the region. There is data available on the programs startup years, coverage (households and individuals), and on cash transfers in US dollars.

The main limitation of this database is that the coverage of beneficiaries and the cash transfers data is published on an aggregate basis. Therefore, it does not allow obtaining clear and useful conclusions to establish the scope of these programs regarding the population living with incomes below the poverty line. Due to the considerable difference in population and beneficiaries of these programs among the countries of the region, it is necessary to readjust the ECLAC data by taking into consideration the targeted population of the CCTs; i.e. data must be transformed into per capita (per beneficiary) values. It is also essential to adjust the data on the social investment of the programs 
taking into account the monetary value of the national poverty line. In other words, the coverage of benefits must be assessed taking into consideration the proportion of cash transference invested by the government on CCTs over the value of the poverty line.

The ECLAC uses the basic basket of food and services to set the value of the monetary poverty line and the basic basket of food to set the value of the extreme poverty line. According to these indicators, anyone with an income/consumption below the monetary lines will be considered in poverty or extreme poverty, respectively. Several researchers have highlighted criticisms about the use of monetary poverty lines as the only means to present poverty (BOLTVINIK, 2003; MEHROTRA and DELAMONICA, 2007; CRUZ-MARTÍNEZ, 2015a, 2015b). In this paper the multidimensionality of poverty is also acknowledged, as well as the multiplicity of deprivations suffered by individuals on poverty. For this reason, it is important to emphasize that the official indicators published in the ECLAC refer to the population on monetary poverty. That is, people in poverty suffering monetary deprivations. Nonetheless, this data do not take into account the entire population in poverty, because they do not consider other individual deprivations (eg., education, health, sanitation, potable water etc.).

In this paper I argue for an alternative proposal to evaluate and assess the CCTs, using the most recent data ${ }^{(5)}$ published by the ECLAC (2014). Two indicators were constructed, with the purpose of presenting a more objective view of the programs in terms of effective coverage of benefits and beneficiaries of the population in income poverty. According to Martínez et al. (2011) the concept 'effective coverage' was introduced by the World Health Organization (WHO) in the publication of Shengelia et al. (2003), as an intermediate objective of the health system within the evaluation of the performance of health systems. The purpose of the authors with this concept was to present the potential health gain after a public health policy. This research seeks to bring the effective coverage concept developed by WHO to the CCTs. Thus, the effective coverage of beneficiaries is a measure that provides information about the potential proportion of population living in monetary poverty WHO benefits from the CCTs, and the effective coverage of benefits is a measure that provides information about the potential value of the poverty line invested by the $\mathrm{CCTs}^{(6)}$. The purpose is to adjust the aggregate indicators of the CCTs taking into account the target population of those programs.

It must be noted that these alternative indicators will have a percentage of error. First, we must recognize the possibility of finding CCTs beneficiaries with incomes above the poverty line (inclusion errors). Secondly, there may be individuals with incomes below the poverty line that are not beneficiaries of the programs (exclusion errors). Third, the data used refer to monetary deprivation and do not take into account other individual deprivations or the conceptualization of poverty from the capability approach. So the final score of the two indicators will show the maximum possible coverage for the CCTs target population assuming perfect selectivity.

(5) Latest data as of July 2015.

(6) This indicator does not consider the 'real' monetary resources received by beneficiaries but rather it takes into account public investment per capita of these programs as a reference. Hence this paper makes reference to the potential coverage of benefits and not the real coverage of benefits. 


\subsection{EFFECTIVE COVERAGE OF BENEFICIARIES IN THE CCTS}

The first alternative indicator was named effective coverage of beneficiaries ${ }^{(7)}$. It was necessary to collect data on the proportion of the population living in monetary poverty and extreme poverty, and the number of the main CCTs beneficiaries in each country. Assuming a perfect selectivity - which is expected not to be true - the quotient between the coverage (CCTs beneficiaries) and the population with incomes below the extreme poverty line, displays the effective coverage of beneficiaries in extreme monetary poverty. Similarly, the quotient between the coverage (CCTs beneficiaries) and the population with incomes below the poverty line, show the effective coverage of beneficiaries in monetary poverty (see Table 2).

$$
\text { Effective coverage of beneficiaries }=\frac{\text { \# of CCTs beneficiaries }}{\# \text { of the population in poverty/extreme poverty }}
$$

After calculating the effective coverage of beneficiaries in each of the CCTs, it is possible to confirm that the results do not correspond with the aggregated data presented by the ECLAC. The CCT effectiveness should not be operationalized taking into account the ratio of beneficiaries over the total population, but the ratio of beneficiaries over the CCTs target population.

Table 2 shows that nine major CCTs in the region have a level of effective coverage of beneficiaries higher than the total population in extreme monetary poverty ${ }^{(8)}$. These programs are: 'Bolsa Familia' (Brazil), 'Chile Solidario' (Chile), 'Más Familias en Acción' (Colombia), 'Bono de Desarrollo Humano' (Ecuador), 'Mi Bono Seguro' (Guatemala), 'Oportunidades' (México), 'Juntos' (Perú), 'Progresando con Solidaridad' (Dominican Republic) and 'Asignaciones Familiares' (Uruguay). Because in these nine countries the coverage of CCTs is greater than the population in extreme monetary poverty, the calculation provided in the column "effective coverage of beneficiaries in extreme poverty" is above 1.00. That is, these nine programs are the only ones who have a greater coverage of beneficiaries than the number of people with income below the extreme poverty line.

There are also differences between CCTs with lower effective coverage of beneficiaries and lower aggregate coverage. Data shows that there are three CCTs with a ratio of beneficiaries lower than $50 \%$ of the population in extreme monetary poverty. These are: 'Avancemos' (Costa Rica), 'Comunidades Solidarias Rurales' (El Salvador) and 'Tekoporã' (Paraguay).

The results in terms of monetary poverty were less encouraging. Only three of the nine CCTs with coverage of beneficiaries higher than the number of individuals on extreme poverty exhibited an effective coverage of beneficiaries greater than the population in monetary poverty. These are: 'Asignaciones Familiares', 'Bolsa Familia' and 'Bono

(7) The study took into consideration the individuals and not the household as a unit of analysis since the available data favored the observation of effective coverage of beneficiaries. In addition, the use of individuals favors the visualization of effective coverage in per capita terms.

(8) Due to lack of comparable data with ECLAC poverty and extreme poverty line, it was impossible to calculate the effective coverage of beneficiaries for the cases of Argentina, Haiti, Jamaica and Trinidad and Tobago. 
de Desarrollo Humano'. On the other hand, seven CCTs presented an effective coverage of beneficiaries on monetary poverty below $50 \%$.

There are considerable differences between the CCTs with the highest and lowest effective coverage of beneficiaries. The Uruguayan CCT had the highest effective coverage of beneficiaries in extreme poverty and monetary poverty, while the Paraguayan exhibited the lowest effective coverage of beneficiaries in extreme poverty, and the Salvadoran had the lowest effective coverage of beneficiaries in monetary poverty. The Uruguayan CCT exhibited an effective coverage of beneficiaries in extreme poverty 61.54 times higher than the Paraguayan CCT, while the effective coverage of beneficiaries is 19.13 times the Salvadoran CCT.

\subsection{EFFECTIVE COVERAGE OF BENEFITS IN THE CCTS}

The data of the effective coverage of beneficiaries does not provide enough information by itself to determine the effectiveness of the CCT. It is also necessary that the cash benefit invested by the state be sufficient to allow the beneficiaries to overcome the extreme poverty line. This is the threshold that utilitarian and monetary poverty advocates consider as 'sufficient' for an individual to have a happy and dignified life without deprivations on any welfare area. A second alternative indicator was constructed in order to assess whether or not the average public spending invested on beneficiaries is sufficient to overcome the monetary poverty line. This indicator is the effective coverage of benefits.

The effective coverage of benefits in terms of monetary poverty reflects the proportion of state investment per beneficiary of each CCT over the value of the monetary poverty line. In other words, this indicator is constructed by the quotient between the CCTs expenditure per beneficiary and the value of the monetary poverty line. On the other hand, the effective coverage of benefits in terms of extreme poverty reflects the proportion of state investment per beneficiary over the value of the extreme poverty line. That is, the quotient between the CCTs expenditure per beneficiary and the value of the extreme poverty line (see Table 3). The amount of spending per beneficiary is calculated by the quotient of total state spending in each CCT over the number of individuals benefiting from these programs. The value of the poverty line and the extreme poverty line is annual, per person and makes reference to the urban area. The data comes from the CEPALSTAT, the database of the ECLAC (n/d).

$$
\text { Effective coverage of benefits }=\frac{\text { state spending per CCT beneficiar } y^{10}}{\text { monetary value of the poverty/extreme poverty line }}
$$

Why not simply use the value of spending per beneficiary as a comparative measure to determine the most effective CCT in terms of coverage of benefits? The spending per beneficiary can be used as a comparative measure of the CCTs investment of economic resources per beneficiary. However, this measure does not take into consideration how much does the public investment represents in regards of the monetary value of the poverty/extreme poverty line. For example, knowing that the CCT of country X invests one thousand dollars per beneficiary and the CCT of country Y invests two thousand dollars 
per beneficiary, sheds us some information about the public investment efforts among the CCTs, but it does not give us any information on the proportion of this investment over the national poverty line value. Now, the effective coverage of benefits works as an alternative indicator of the CCTs role on monetary poverty because it presents an approximated value of the poverty and extreme poverty line that is invested in each of the beneficiaries.

After analyzing the Table 3, we can confirm that in fact ten CCTs exhibited an investment per beneficiary worth over the extreme poverty line. While this number is reduced by $30 \%$ when considering the investment per beneficiary according to the poverty line. 'Asignación universal por hijo para protección social' (Argentina) and 'Avancemos' (Costa Rica) are the two CCTs with the highest effective coverage of benefits in terms of poverty and extreme poverty. The CCTs from Ecuador, Guatemala, Honduras, Mexico, Paraguay and Dominican Republic are the only ones that exhibited an effective coverage of benefits below the value of the extreme poverty line. These six are joined by the Bolivian, Colombian and Peruvian CCTs as the programs with an effective coverage of benefits inferior to the value of the poverty line.

Data shows that there are three CCTs with an effective coverage of benefits lower than $50 \%$ of the poverty and extreme poverty line value. These are: 'Mi Bono Seguro' (Guatemala), 'Bono 10.000 Educación, Salud y Nutrición' (Honduras) and 'Tekoporã' (Paraguay). 'Oportunidades' (México) and 'Bono de Desarrollo Humano' (Ecuador) complete the list of the five conditional cash transfer programs with an effective coverage of benefits lower than $50 \%$ of the poverty line value.

As with the effective coverage of beneficiaries, there are also considerable differences between the CCTs with the highest and lowest effective coverage of benefits. The Argentine CCT showed the highest effective coverage of benefits while the Paraguayan displayed the lowest effective coverage of benefits. The Argentine CCT exhibited an effective coverage of benefits in terms of extreme monetary poverty 92.27 times higher than the Paraguayan CCT, while the effective coverage of benefits in terms of monetary poverty is 82.04 times higher.

\subsection{EFFECTIVE JOINT COVERAGE OF BENEFITS AND BENEFICIARIES}

Does any conditional cash transfer programs (CCT) exhibits an effective joint coverage of benefits and beneficiaries? Five of the nine CCTs with an effective coverage of beneficiaries greater than the total population in extreme monetary poverty invest higher monetary sums per beneficiary than the extreme poverty line value. And only two programs combine an effective coverage of beneficiaries greater than the population on monetary poverty with an effective coverage of benefits higher than the poverty line value. That is, only the Brazilian, Chilean, Colombian, Peruvian and Uruguayan CCTs exhibited a high effective coverage of beneficiaries and benefits in terms of the extreme poverty line. And only the Brazilian and Uruguayan programs showed a combined high effective coverage of beneficiaries and benefits according to the poverty line. While other programs may have a high coverage of beneficiaries on monetary poverty/ extreme poverty (as applicable), the public investment per beneficiary was not enough 
to overcome the respective monetary threshold. Likewise, there are programs with high effective coverage of benefits but this is not accompanied by a high effective coverage of beneficiaries.

These data highlight the need not to only pay attention to the number of beneficiaries of the programs, but also the importance of considering the average investment per capita by each program. In this case, to consider whether the CCTs average investment per capita enables beneficiaries to acquire the necessary income to overcome the extreme poverty line - basic food basket - or the poverty line - basic basket of food and services. Therefore, it is necessary to take into consideration that the effectiveness of these programs to alleviate monetary poverty will depend - at least - on the combination of two factors: (1) an effective coverage of the population in monetary poverty/extreme poverty, together with (2) a monetary coverage sufficient to allow beneficiaries consume the basic basket of food and services.

\section{CONCLUSION}

The main difference, between the alternative indicators of effective coverage and the indicators published in the 'Non-contributory social protection Programmes in Latin America and the Caribbean' database, is that coverage levels of programs in this study used the targeted population (individuals on monetary poverty) as the unit of analysis instead of aggregated data of the total population. The CCTs are programs targeted towards the population on monetary poverty, therefore to assess their effectiveness in terms of coverage of benefits and beneficiaries, attention must be paid to the reality perceived by the targeted population.

Several conclusions were drawn regarding the data and analysis from the constructed indicators: effective coverage of beneficiaries and effective coverage of benefits. First, only three CCTs have an effective coverage of beneficiaries higher than the percentage of the population on monetary poverty. In addition, six programs fulfill the same objective, but in terms of population on extreme monetary poverty. While three CCTs have an effective coverage of beneficiaries lower than $50 \%$ of the population in extreme poverty and seven have an effective coverage of beneficiaries below $50 \%$ of the population in monetary poverty.

The data confirm that there are ten CCTs with an effective coverage of benefits higher than the extreme poverty line value. While seven programs had an effective coverage of benefits higher than the poverty line value. Three CCTs showed an effective coverage of benefits below the $50 \%$ of the extreme poverty line value and five CCTs exhibited an effective coverage of benefits below the $50 \%$ of the poverty line value. It is necessary to take into consideration that this indicator shows the estimated state investment per beneficiary in these programs, but it does not represent the actual average of the individual transfer received by the beneficiaries.

These data highlight the need not to only pay attention to the number of beneficiaries of the programs, but also the importance of considering the average investment per capita by each program. In this case, to consider whether the CCTs average invest- 
ment per capita enables beneficiaries to acquire the necessary income to overcome the extreme poverty line - basic food basket - or the poverty line - basic basket of food and services. Therefore, it is necessary to take into consideration that the effectiveness of these programs to alleviate monetary poverty will depend - at least - on the combination of two factors: (1) an effective coverage of the population in monetary poverty/ extreme poverty, together with (2) a monetary coverage sufficient to allow beneficiaries consume the basic basket of food and services.

The debate must continue in order to examine the best ways to eradicate poverty in the region and reduce the high levels of inequality. The important thing is to recognize that the development and extension of targeted programs as the CCTs are not enough, by themselves, to eradicate poverty in all its facets and dimensions.

The alternative indicators proposed in the paper could be incorporated into the 'Non-contributory social protection Programmes in Latin America and the Caribbean' ECLAC database in order to facilitate data for alternative analysis particularly focused on the targeted population of these programs. The cost in time and resources for the database would be practically insignificant. In addition, the methodology used to obtain the indicators is simple and easy to understand. Further analyses could incorporate time series analysis of the effective coverage of benefits and beneficiaries in order to illustrate the progress of the CCTs coverage over time.

In addition, examine the explanatory power of the CCTs on monetary poverty and extreme poverty using regression analysis with panel data. Another interesting analysis that could be carried out is to examine the proportion of effective coverage of benefits over the personal disposable income in each of the cases. This will facilitate understanding the relative weight of these benefits over the average income of the working class, something similar to a replacement rate analysis. More ideal would be to have data on the monetary value of all transfers, excluding personnel and administrative costs, in order to be able to calculate the effective coverage of benefits taking into consideration the actual transfer received by beneficiaries, and not an estimated value of the state investment.

\section{REFERENCES}

ADATO, Michelle; HODDINOTT, John. Conditional cash transfers in Latin America. Baltimore: John Hopkins University Press, International Food Policy Research Institute, 2010.

BOLTVINIK, Julio. Conceptos y medición de la pobreza: la necesidad de ampliar la Mirada. Papeles de Población, n.38, p. 9-25, 2003.

CORTÉS, Fernando; BANEGAS, Israel; SOLÍS, Patrício. Pobres con Oportunidades: México 2002-2005. Estudios Sociológicos, v. XXV, n. 73, p. 3-40, 2007.

CRUZ-MARTÍNEZ, Gibrán. Análisis multidimensional del Estado de bienestar emergente y la pobreza en América Latina y el Caribe: Puerto Rico como estudio de caso. Tesis Doctoral, Universidad Complutense de Madrid. Madrid, 2015a.

CRUZ-MARTÍNEZ, Gibrán. Balance alternativo de indicadores de pobreza en los ODM para América Latina y el Caribe: ¿Medir el éxito como aceleración del progreso o consecución de las metas? Relaciones Internacionales, n. 28, p.11-36, 2015 b. 
DEL VALLE, Alejandro H. Comparando regímenes de bienestar en América Latina. Revista Europea de Estudios Latinoamericanos y del Caribe, n.88, p. 61-76, 2010.

DRAIBE, Sonia; RIESCO, Manuel. El Estado de bienestar social en América Latina: una nueva estrategia de desarrollo. Documento de Trabajo, n. 31, Fundación Carolina-CeALCI. Disponível em: https:// dialnet.unirioja.es/servlet/articulo? codigo=3049425. Acceso en 21 de nov. 2015.

ECONOMIC COMISSION FOR LATIN AMERICAN AND THE CARIBBEAN (ECLAC). Anuario estadístico de América Latina y el Caribe. Santiago de Chile: Naciones Unidas, 2007.

ECONOMIC COMISSION FOR LATIN AMERICAN AND THE CARIBBEAN (ECLAC). Panorama social de América Latina: 2009. Santiago de Chile: Naciones Unidas, 2010.

ECONOMIC COMISSION FOR LATIN AMERICAN AND THE CARIBBEAN (ECLAC). Non-contributory social protection programmes in Latin America and the Caribbean database. United Nations, 2014. Disponible en: http://dds.cepal.org/bdptc/en/contact.php. Acceso en: 21 de nov.de 2015.

ECONOMIC COMISSION FOR LATIN AMERICAN AND THE CARIBBEAN (ECLAC). Los programas de transferencias condicionadas y el Mercado laboral. Coyuntura laboral en América Latina y el Caribe, Mayo, n.10, 2014. Disponible en: http://repositorio.cepal.org/bitstream/handle/11362/36896/ S2014311_es.pdf? sequence=1. Acceso en: 21 de nov.de 2015.

ECONOMIC COMISSION FOR LATIN AMERICAN AND THE CARIBBEAN (ECLAC). Databases and statistical publications. United Nations, n/d. Disponible en: http://estadisticas.cepal.org/cepalstat/ web_cepalstat/Portada.asp?idioma=i. Acceso en: 21 de nov. de 2015.

ESPING-ANDERSEN, Gosta. The three worlds of Welfare capitalism. Princeton, New Jersey: Princeton University Press, 1990.

KABEER, Naila. Resources, agency, achievements: reflections on the measurement of women's empowerment. Development and Change, v. 3, n.3 0, p. 435-464, 1999.

LOMELÍ, Enrique V. Conditional cash transfer programs: achievements and illusions. Global Social Policy, v. 9, n. 2, p.167-171, 2009.

MARTÍNEZ, Sandra; CARRASQUILLA, Gabriel; GUERRERO, Ramiro et al. Cobertura efectiva de las intervenciones en salud de América Latina y el Caribe: métrica para evaluar los sistemas de salud. Salud Pública de México, v. 2, n. 53, p.78-84, 2011.

MEHROTRA, Santosh; DELAMONICA, Enrique. Eliminating human poverty: macroeconomic and social policies for equitable growth. London: Zed Books, 2007.

MOLINARI, Michelle. Programa de transferencias condicionadas benefician a más de 100 millones de personas en la región. Comunicados de la CEPAL, 2010.

REIMERS, Fernando; DESHANO DA SILVA, Carol; TREVINO, Ernesto. Where is the "education" in conditional cash transfers in education? UNESCO Institute for Statistics Working Paper, n. 4, 2006.

SLATER, Rachel. Cash transfers, social protection and poverty reduction. International Journal of Social Welfare, v. 3, n. 20, p. 250-259, 2011.

STAMPINI, Marco; TORNAROLLI, Leopoldo. The growth of conditional cash transfers in Latin America and the Caribbean: did they go too far? IZA Policy Paper Series, n. 49, 2012.

TABBUSH, Constanza. Latin American women's protection after adjustment: a feminist critique of conditional cash transfers in Chile and Argentina. Oxford Development Studies, v. 4, n. 38, p. 437459, 2010.

VILLATORIO, Pablo; RIVERA, Elizabeth. La cohesion social en los países desarrollados: conceptos e indicadores. Serie Estudios Estadísticos y Prospectivos, v. 55. Naciones Unidas: Santiago, 2007. 


\section{APPENDIX}

TABLE 1.

Main Conditional Cash Transfer Programs in nineteen countries of Latin AMERICA AND THE CARIBBEAN

\begin{tabular}{|c|c|c|c|c|c|c|}
\hline \multirow[t]{2}{*}{ Country } & \multirow[t]{2}{*}{ CCT } & \multirow[t]{2}{*}{$\begin{array}{c}\text { Date } \\
\text { of } \\
\text { Start }\end{array}$} & \multicolumn{2}{|c|}{ Aggregated Coverage } & \multicolumn{2}{|c|}{$\begin{array}{c}\text { Monetary Transferences } \\
\text { USD }\end{array}$} \\
\hline & & & Households & Individuals & $\begin{array}{c}\text { Minimum per } \\
\text { beneficiary }\end{array}$ & $\begin{array}{l}\text { Maximum } \\
\text { per family }\end{array}$ \\
\hline Argentina & $\begin{array}{l}\text { Asignación Universal } \\
\text { por Hijo para Protec- } \\
\text { ción Social }\end{array}$ & 2009 & $1.897 .485^{c}$ & $3.540 .717^{c}$ & $67,30^{b}$ & $273,40^{b}$ \\
\hline Bolivia & Bono Juancito Pinto & 2006 & $398.267^{b}$ & $1.625 .123^{d}$ & $28,74^{\mathrm{b}}$ & NA \\
\hline Brazil & Bolsa Familia & 2003 & $13.770 .339^{c}$ & $56.458 .390^{c}$ & $3,91^{\mathrm{b}}$ & $284,39^{b}$ \\
\hline Chile & Chile Solidario & 2002 & $263.995^{d}$ & $1.108 .779^{d}$ & $8,68^{d}$ & Varies \\
\hline Colombia & Más Familias en Acción & 2001 & $2.681 .552^{\mathrm{b}}$ & $11.262 .518^{\mathrm{b}}$ & $3,69^{b}$ & $94,21^{\mathrm{b}}$ \\
\hline Costa Rica & Avancemos & 2006 & $42.839^{b}$ & $171.354^{b}$ & $29,96^{\mathrm{b}}$ & $159,81^{b}$ \\
\hline Ecuador & $\begin{array}{l}\text { Bono de Desarrollo } \\
\text { Humano }\end{array}$ & 2003 & $1.225 .929^{c}$ & $6.418 .479^{c}$ & $10,42^{c}$ & NA \\
\hline El Salvador & \begin{tabular}{|l} 
Comunidades Solida- \\
rias Rurales
\end{tabular} & 2005 & 80.22 & 411 & 3,1 & NA \\
\hline Guatemala & Mi Bono Seguro & 2012 & $766.000^{b}$ & $4.213 .000^{\mathrm{b}}$ & $19,84^{\mathrm{c}}$ & $39,68^{c}$ \\
\hline Haiti & Ti Manman Cheri & 2012 & $\mathrm{NA}$ & $70.772^{\mathrm{c}}$ & 10 & 20 \\
\hline Honduras & $\begin{array}{l}\text { Bono } 10.000 \text { Educación, } \\
\text { Salud y Nutrición }\end{array}$ & 2010 & $411.843^{d}$ & $2.347 .505^{d}$ & $8,82^{d}$ & $\operatorname{Var}$ \\
\hline Jamaica & $\begin{array}{l}\text { Programme of Advan- } \\
\text { cement trough Health } \\
\text { and Education }\end{array}$ & 2001 & NA & $307.000^{f}$ & $7,40^{f}$ & Varies \\
\hline Mexico & Oportunidades & 1997 & 6.600 & $000^{\mathrm{b}}$ & 32,3 & $33^{b}$ \\
\hline Panamá & Red de Oportunidades & 2006 & $72.563^{b}$ & $288.956^{d}$ & $16,67^{\mathrm{a}}$ & $75,00^{a}$ \\
\hline Paraguay & Tekoporã & 2005 & $99.015^{d}$ & $554.484^{\mathrm{d}}$ & $24,41^{\mathrm{d}}$ & $61,54^{\mathrm{d}}$ \\
\hline Peru & Juntos & 2005 & $719.000^{b}$ & $3.572 .542^{\mathrm{c}}$ & $17,59^{\mathrm{b}}$ & $77,38^{\mathrm{b}}$ \\
\hline $\begin{array}{l}\text { Dominican } \\
\text { Republic } \\
\end{array}$ & \begin{tabular}{|l|}
$\begin{array}{l}\text { Progresando con Soli- } \\
\text { daridad }\end{array}$ \\
\end{tabular} & 2012 & $692.828^{a}$ & $2.355 .615^{\mathrm{a}}$ & $37,45^{\mathrm{a}}$ & $100,07^{a}$ \\
\hline $\begin{array}{l}\text { Trinid ad } \\
\text { and Tobago }\end{array}$ & $\begin{array}{|lr|}\text { Targeted Conditional } \\
\text { Cash Transfer Program } \\
\end{array}$ & 2005 & NA & $24.260^{g}$ & $64,86^{\mathrm{g}}$ & $110,7^{g}$ \\
\hline Uruguay & Asignaciones Familiares & 2008 & $131.926^{c}$ & $527704^{c}$ & $49,49^{c}$ & $346,45^{c}$ \\
\hline \multicolumn{7}{|c|}{$\begin{array}{l}\text { Notes: } \\
\text { a/ Data from 2014; b/ Data from 2013; c/ Data from 2012; d/ Data from 2011; e/ Data from 2010; f/ } \\
\text { Data from 2009; g/ Data from } 2008\end{array}$} \\
\hline \multicolumn{7}{|c|}{$\begin{array}{l}\text { The CCTs in Table A. } 1 \text { meet any of the following conditions: a) is the CCT nationwide or, b) is the CCT } \\
\text { with the highest coverage in the country. In order to avoid duplication of beneficiaries and be able to } \\
\text { perform a more accurate comparison of the scope of CCTs in the region, regional programs and / or } \\
\text { programs fulfilling a specific purpose were excluded. In other words, this table shows the data of the } \\
\text { main CCT in each of the countries. }\end{array}$} \\
\hline \multicolumn{7}{|c|}{ NA: Not available } \\
\hline & it var & umb & ub & $\mathrm{s}$ beneffited & & \\
\hline
\end{tabular}

Source: ECLAC (2014) 
TABLE 3

EFFECTIVE COVERAGE OF BENEFITS OF THE CONDITIONAL TRANSFER PROGRAMMES IN Latin AMERICA AND tHe CARIBbEAN, TAKING INTO CONSIDERATION THE RATIO OF STATE INVESTMENT PER BENEFICIARY OVER THE VALUE OF THE POVERTY AND EXTREME POVERTY LINE

\begin{tabular}{|c|c|c|c|c|c|c|}
\hline Country & CCT & \begin{tabular}{|c|} 
Spen- \\
ding per \\
bene- \\
ficiary \\
(USD) \\
\end{tabular} & $\begin{array}{c}\text { Value of } \\
\text { the extre- } \\
\text { me po- } \\
\text { verty line } \\
\text { (USD) }\end{array}$ & $\begin{array}{c}\text { Effective } \\
\text { coverage } \\
\text { of benefits } \\
\text { (extreme po- } \\
\text { verty line) } \\
\end{array}$ & \begin{tabular}{|l}
$\begin{array}{l}\text { Value } \\
\text { of the } \\
\text { poverty } \\
\text { line } \\
\text { (USD) }\end{array}$ \\
\end{tabular} & $\begin{array}{c}\begin{array}{c}\text { Effective } \\
\text { coverage } \\
\text { of benefits } \\
\text { (poverty } \\
\text { line) }\end{array} \\
\end{array}$ \\
\hline Argentina & $\begin{array}{l}\text { Asignación Universal } \\
\text { por Hijo para Protec- } \\
\text { ción Social }\end{array}$ & 695,26 & 49,9 & 13,933 & 100,9 & 6,891 \\
\hline Bolivia & Bono Juancito Pinto & 61,88 & 50,1 & 1,235 & 87,2 & 0,710 \\
\hline Brazil & Bolsa Familia & 188,00 & 60,5 & 3,107 & 136,7 & 1,375 \\
\hline Chile & Chile Solidario & 299,56 & 70,0 & 4,279 & 120,7 & 2,482 \\
\hline Colombia & Más Familias en Acción & 77,61 & 51,3 & 1,513 & 121,7 & 0,638 \\
\hline Costa Rica & Avancemos & 559,57 & 84,0 & 6,662 & 154,9 & 3,612 \\
\hline $\begin{array}{l}\text { Dominican } \\
\text { Republic }\end{array}$ & $\begin{array}{l}\text { Progresando con Solida- } \\
\text { ridad }\end{array}$ & 57,47 & 61,9 & 0,928 & 114,3 & 0,503 \\
\hline Ecuador & $\begin{array}{l}\text { Bono de Desarrollo Hu- } \\
\text { mano }\end{array}$ & 41,66 & 62,0 & 0,672 & 111,2 & 0,375 \\
\hline El Salvador & $\begin{array}{l}\text { Comunidades Solidarias } \\
\text { Rurales }\end{array}$ & 192,07 & 51,4 & 3,737 & 102,3 & 1,878 \\
\hline Guatemala & Mi Bono Seguro & 23,80 & 61,5 & 0,387 & 123,0 & 0,194 \\
\hline Haiti & Ti Manman Cheri & 183,69 & NA & NA & NA & NA \\
\hline Honduras & $\begin{array}{l}\text { Bono } 10.000 \text { Educación, } \\
\text { Salud y Nutrición }\end{array}$ & 23,82 & 60,6 & 0,393 & 119,8 & 0,199 \\
\hline Jamaica & $\begin{array}{l}\text { Programme of Advance- } \\
\text { ment trough Health and } \\
\text { Education }\end{array}$ & 111,18 & NA & NA & NA & NA \\
\hline Mexico & Oportunidades & 88,59 & 104,5 & 0,848 & 184,2 & 0,481 \\
\hline Panama & Red de Oportunidades & 154,00 & 62,2 & 2,476 & 115,1 & 1,338 \\
\hline Paraguay & Tekoporã & 11,11 & 73,7 & 0,151 & 133,0 & 0,084 \\
\hline Peru & Juntos & 76,93 & 41,1 & 1,872 & 113,8 & 0,676 \\
\hline $\begin{array}{l}\text { Trinidad and } \\
\text { Tobago }\end{array}$ & $\begin{array}{l}\text { Targeted Conditional } \\
\text { Cash Transfer Program }\end{array}$ & 680,43 & NA & NA & NA & NA \\
\hline Uruguay & Asignaciones Familiares & 435,63 & 112,4 & 3,876 & 205,5 & 2,120 \\
\hline \multicolumn{7}{|c|}{$\begin{array}{l}\text { Notes: } \\
\text { The value of the monetary poverty line and the extreme poverty line is annual, per person and makes } \\
\text { reference to the urban area. Data of spending per beneficiary and of the poverty and extreme poverty } \\
\text { line correspond to the years of the coverage of individuals for each CCT. Spending per beneficiary } \\
\text { includes transfers plus the administrative costs of the program. Due to scarcity of data, the value of the } \\
\text { budgeted expenditure - rather than the actual expenditure - was used to operationalize the spending } \\
\text { per beneficiary for the cases of Colombia, El Salvador, Haiti and Jamaica. } \\
\text { NA: Not available }\end{array}$} \\
\hline
\end{tabular}

Source: ECLAC (2014, n/d) 
